Australian Journal of

Educational Technology

\title{
Definitions of instructional control in learning environments
}

\author{
Som Naidu, PhD \\ University of Southern Queensland
}

\begin{abstract}
A fundamental question in the design of learning environments is determining the nature of instructional control which will facilitate optimal learning outcomes. The assumptions that increased control in the hands of learners will produce enhanced learning outcomes is untenable. This short paper reviews a select body of research with varying types and levels of control in learning environments and presents a summary of operational definitions of control applied in those studies. Analysis of these definitions revealed variations in the amount of control allowed which is most meaningful if represented on a continuum ranging from maximum program control on the one hand, to maximum learner control on the other. The impacts of control in learning environments is briefly discussed.
\end{abstract}

Locus of instructional control in learning environments whether CAI (computer-assisted instruction) or CAVI (computer-assisted video instruction) may range from maximal program control on the one hand to maximal learner control on the other. Program control refers to a learning environment in which the selection and sequence of instructional stimuli are made without strategy inputs from the learner, while learner control refers to one where the learner is responsible for the learning strategy. The condition in which there is maximal or complete learner control of everything (ie., learner control) has been described by Snow (1980) as the 'Adult Scholar Model'; and one where the learner has virtually no control (ie., program control) as 'Child Robot Model'. In the former the learner commands complete independence and self direction while in the latter he/she is subjected to fixed tasks, a fixed pace, and no remediation. 
As it is now clear that each learner and learning context is different and that learners will always differ in their preferences for self-control, and also to the extent that they may be able to exercise it effectively for their own benefit, the program/learner control dichotomy in the design and arrangement of learning environments is far from adequate. The assumption that all learners know what is best for themselves at any given moment in an instructional sequence, and that all are capable of acting on this knowledge is untenable, at least for many learners (Snow, 1980). The current feeling is that one can perhaps give control to all of the learners some of the time, and to some of the learners all of the time, but one should probably not give control to all of the learners all of the time. A fundamental instructional design question is to determine what kind of control should be given and when.

Recent research has identified the existence of a whole range of possibilities in the arrangement of learning environments with varying degrees of learner and program control so much so that instructional control in learning environments is now represented more fully and appropriately as a continuum varying or ranging from maximum program control on the one hand to maximum learner control on the other. Between the two there is a range of variations, each recognisable by its placement on the continuum.

The choice of the nature and degree of control in instruction is the net result of a variety of factors pertaining to the learner, the learning environment, and the subject matter being learned. As learners, learning environments, and subject matter become more complex, the design and arrangement of learning environments have become equally complex. The accompanying chart is a summary of recent research on instructional control in learning environments. It is intended to show: a) how various researchers and authors have defined locus of instructional control, and b) the nature of the overlap.

\section{Summary comment}

Two issues arising from the above chart are worth further comment. First, clearly there is general concurrence amongst those cited on the existence of degrees of instructional control in the arrangement of learning environments ranging from program controlled to learner controlled, and with variations in between. The terminology is not quite the same but the meaning is similar. 


\begin{tabular}{|c|c|c|c|}
\hline Source & \multicolumn{3}{|c|}{ Definition } \\
\hline $\begin{array}{l}\text { Holmes, } \\
\text { Robson \& } \\
\text { Steward } \\
(1985)\end{array}$ & $\begin{array}{l}\text { Program Control } \\
\text { Frame displays } \\
\text { and selections } \\
\text { made by the } \\
\text { computer } \\
\text { program. }\end{array}$ & & $\begin{array}{l}\text { Learner Control } \\
\text { Students have } \\
\text { pre-instructional } \\
\text { advice on self- } \\
\text { estimation of } \\
\text { comprehension } \\
\text { and decision } \\
\text { making process } \\
\text { on selection of } \\
\text { next frame. }\end{array}$ \\
\hline $\begin{array}{l}\text { Ross \& } \\
\text { Rakow } \\
\text { (1981) }\end{array}$ & $\begin{array}{l}\text { Program Control } \\
\text { Examples } \\
\text { adapted to } \\
\text { subjects' pretest } \\
\text { scores. Prescri- } \\
\text { ptions varied } \\
\text { according to } \\
\text { subjects' scores. }\end{array}$ & $\begin{array}{ll}\text { Lecture } & \text { Non-Adaptive } \\
\text { Students could } & \text { Five examples } \\
\text { attend either one } & \text { selected per rule } \\
\text { of two lecture } & \text { considered as } \\
\text { presentations. } & \text { optimum. }\end{array}$ & $\begin{array}{l}\text { Learner Control } \\
\text { Examples } \\
\text { selected by } \\
\text { subjects who } \\
\text { could ask for } \\
\text { more. }\end{array}$ \\
\hline Gay (1986) & $\begin{array}{l}\text { Program Control } \\
\text { Computer con- } \\
\text { trolled present- } \\
\text { ation of concepts } \\
\text { in hierarchical } \\
\text { form with } \\
\text { remediation and } \\
\text { review. Student } \\
\text { controlled pace. }\end{array}$ & & $\begin{array}{l}\text { Learner Control } \\
\text { Student control } \\
\text { of pace, } \\
\text { sequence, depth, } \\
\text { amount of } \\
\text { practice, mode } \\
\text { of presentation } \\
\text { and type of } \\
\text { content. }\end{array}$ \\
\hline Judd (1972) & & $\begin{array}{ll}\text { Forced Group: } & \text { Yoked Control } \\
\text { Forced Group: } & \text { Members paired } \\
\text { directed through } & \text { with learner } \\
\text { sequence dictat- } & \text { control group. } \\
\text { ed by task analy- } & \\
\text { sis of subject } & \\
\text { matter. } & \end{array}$ & $\begin{array}{l}\text { Learner Control } \\
\text { Determined } \\
\text { their own } \\
\text { sequence } \\
\text { through the } \\
\text { materials. }\end{array}$ \\
\hline Judd (1972) & $\begin{array}{l}\text { Program Control } \\
\text { Learners } \\
\text { proceed through } \\
\text { fix-ed, optimally } \\
\text { ordered } \\
\text { sequence. }\end{array}$ & & $\begin{array}{l}\text { Learner Control } \\
\text { Student control } \\
\text { over sequence } \\
\text { and selection of } \\
\text { materials. }\end{array}$ \\
\hline Judd (1972) & $\begin{array}{l}\text { Program Control } \\
\text { Order of } \\
\text { presentation } \\
\text { fixed in an } \\
\text { assumed } \\
\text { optimal order } \\
\text { for all } \\
\text { treatments. }\end{array}$ & & $\begin{array}{l}\text { Learner Control } \\
\text { Instructional } \\
\text { decisions based } \\
\text { on learner's } \\
\text { ability to do self- } \\
\text { evaluation. }\end{array}$ \\
\hline
\end{tabular}




\begin{tabular}{|c|c|c|c|c|}
\hline Judd (1972) & $\begin{array}{l}\text { Program Control } \\
\text { No access to } \\
\text { memory sup- } \\
\text { port. (Control } \\
\text { group } 1) .\end{array}$ & & $\begin{array}{l}\text { Learner Control } \\
\text { with Memory } \\
\text { Support } \\
\text { Previous stimuli } \\
\text { and their correct } \\
\text { classifications } \\
\text { displayed on } \\
\text { request. }\end{array}$ & $\begin{array}{l}\text { Learner Control } \\
\text { Memory Supp- } \\
\text { ort always pre- } \\
\text { sented. (Control } \\
\text { group 2). }\end{array}$ \\
\hline $\begin{array}{l}\text { Laurillard } \\
\text { (1984) }\end{array}$ & $\begin{array}{l}\text { Program Control } \\
\text { Designer } \\
\text { determined } \\
\text { route; a subset of } \\
\text { many possible } \\
\text { routes. }\end{array}$ & & & $\begin{array}{l}\text { Student Control } \\
\text { Interface that } \\
\text { allows students } \\
\text { free access to } \\
\text { materials at any } \\
\text { time, in any } \\
\text { sequence. }\end{array}$ \\
\hline $\begin{array}{l}\text { Fisher \& } \\
\text { Blackwell } \\
\text { (1975) }\end{array}$ & $\begin{array}{l}\text { Yoked } \\
\text { No choice of } \\
\text { problem. Same } \\
\text { amount of time } \\
\text { allowed as in the } \\
\text { choice group. }\end{array}$ & & $\begin{array}{l}\text { Choice Control } \\
\text { Selected their } \\
\text { own problems } \\
\text { from CAI. Time } \\
\text { taken (within } \\
\text { limits). }\end{array}$ & \\
\hline $\begin{array}{l}\text { Tennyson, } \\
\text { Robert \& } \\
\text { Rothen } \\
(1979)\end{array}$ & $\begin{array}{l}\text { Program Control } \\
\text { Selection and } \\
\text { sequence made } \\
\text { without learner } \\
\text { input. }\end{array}$ & & $\begin{array}{l}\text { Adaptive Control } \\
\text { Anon-line algor- } \\
\text { ithm adjusts the } \\
\text { learning envir- } \\
\text { onment to indiv- } \\
\text { idual learners or } \\
\text { on-task error } \\
\text { patterns. }\end{array}$ & $\begin{array}{l}\text { Learner Control } \\
\text { Learners resp- } \\
\text { onsible for learn- } \\
\text { ing strategy. } \\
\text { Learners made } \\
\text { decisions about } \\
\text { their own } \\
\text { learning. }\end{array}$ \\
\hline $\begin{array}{l}\text { Tennyson, } \\
\text { Tennyson, } \\
\& \\
\text { Wolfgang } \\
(1980)\end{array}$ & & $\begin{array}{l}\text { Adaptive Control } \\
\text { Strategy } \\
\text { Regulated by } \\
\text { MAIS: - selects } \\
\text { number of inst- } \\
\text { ances presented } \\
\text { to learners based } \\
\text { on pre-task and } \\
\text { on-task perform- } \\
\text { ance - learners } \\
\text { not told how } \\
\text { program opera- } \\
\text { ted: advised of } \\
\text { posttest. }\end{array}$ & & $\begin{array}{l}\text { Learner Control } \\
\text { Strategy } \\
\text { Learners decide } \\
\text { whether or not } \\
\text { to continue } \\
\text { receiving } \\
\text { instances or go } \\
\text { to posttest. }\end{array}$ \\
\hline $\begin{array}{l}\text { Tennyson } \\
\text { (1980) }\end{array}$ & $\begin{array}{l}\text { Adaptive Control } \\
\text { No student } \\
\text { control: } \\
\text { examples } \\
\text { presented in } \\
\text { rational sets. }\end{array}$ & & $\begin{array}{l}\text { Learner-Adaptive } \\
\text { Control } \\
\text { Student control } \\
\text { of amount and } \\
\text { sequence. Advis- } \\
\text { ement on diagn- } \\
\text { osis and } \\
\text { prescription. }\end{array}$ & $\begin{array}{l}\text { Learner Control } \\
\text { Student control } \\
\text { of amount and } \\
\text { sequence: pres- } \\
\text { ented concepts } \\
\text { presented } \\
\text { separately. }\end{array}$ \\
\hline
\end{tabular}




\begin{tabular}{|c|c|c|c|}
\hline $\begin{array}{l}\text { Tennyson } \\
\text { \& Buttery } \\
\text { (1980) }\end{array}$ & $\begin{array}{l}\text { Adaptive Control } \\
\text { Number of } \\
\text { presentations } \\
\text { based on pretask } \\
\text { and on-task } \\
\text { performance. } \\
\text { Sequence } \\
\text { determined by } \\
\text { response } \\
\text { pattern. Program } \\
\text { directions given. }\end{array}$ & $\begin{array}{l}\text { Learner Control } \\
\text { with or without } \\
\text { advisement } \\
\text { With: Advice on } \\
\text { amount of } \\
\text { examples } \\
\text { necessary. } \\
\text { Without: No } \\
\text { advice on } \\
\text { progress or } \\
\text { diagnostic help. }\end{array}$ & $\begin{array}{l}\text { Learner Control } \\
\text { Students decide } \\
\text { whether or not } \\
\text { to continue gett- } \\
\text { ing examples or } \\
\text { go to posttest } \\
\text { informed of pro- } \\
\text { gram directions } \\
\text { and had control } \\
\text { of amount and } \\
\text { sequence. }\end{array}$ \\
\hline $\begin{array}{l}\text { Hannafin } \\
\text { (1984) }\end{array}$ & $\begin{array}{l}\text { External Locus of } \\
\text { Control } \\
\text { Learners follow } \\
\text { a predetermined } \\
\text { path: no indivi- } \\
\text { dual judgement } \\
\text { as to its approp- } \\
\text { riateness. }\end{array}$ & & $\begin{array}{l}\text { Internal Locus of } \\
\text { Control } \\
\text { Individuals con- } \\
\text { trol path, pace } \\
\text { and contingen- } \\
\text { cies of instruct- } \\
\text { ion by specifying } \\
\text { choices from } \\
\text { among a range } \\
\text { of options } \\
\text { presented by } \\
\text { designer. }\end{array}$ \\
\hline $\begin{array}{l}\text { Goetzfried } \\
\& \\
\text { Hannafin } \\
(1985)\end{array}$ & $\begin{array}{l}\text { Linear Control } \\
\text { Sequence same } \\
\text { as Learner } \\
\text { Control with } \\
\text { Advisement, but } \\
\text { no advisement, } \\
\text { no individual } \\
\text { control to review } \\
\text { of select } \\
\text { examples. No } \\
\text { externally } \\
\text { imposed } \\
\text { decisions based } \\
\text { on response } \\
\text { accuracies. } \\
\text { Students } \\
\text { controlled pace. } \\
\text { Followed } \\
\text { predetermined } \\
\text { path. }\end{array}$ & $\begin{array}{l}\text { Adaptive Control } \\
\text { Computer } \\
\text { branched } \\
\text { students for } \\
\text { reteaching or } \\
\text { more examples } \\
\text { based on } \\
\text { response } \\
\text { accuracy. } \\
\text { Students } \\
\text { completed full } \\
\text { lesson. No } \\
\text { control over } \\
\text { pacing or } \\
\text { amount. Mastery } \\
\text { learning } \\
\text { principles used. }\end{array}$ & $\begin{array}{l}\text { Learner Control } \\
\text { with advisement } \\
\text { Internally } \\
\text { controlled CAI. } \\
\text { Students } \\
\text { continuously } \\
\text { advised of } \\
\text { progress and } \\
\text { permitted to } \\
\text { determine if } \\
\text { reteaching or } \\
\text { examples } \\
\text { needed. } \\
\text { Students free to } \\
\text { move from } \\
\text { lesson to lesson } \\
\text { after each } \\
\text { tutorial session. }\end{array}$ \\
\hline
\end{tabular}


text), and type of content (rules, key ideas, examples, or practice). Similar variations in definitions is true of program control and adaptive control.

In the case of the latter point the variation is somewhat more noticeable. Tennyson and Rothen (1979) offer a nice review of various definitions of adaptive control. Their own definition of adaptive control, similar to the others, refers to "strategies which prescribed the optimal amount of instruction necessary to achieve a given objective" (Tennyson \& Rothen, 1977). This variation in the use of terminology is not being pointed out as a criticism but rather as a truism in the literature: a truism necessitated by the need to operationalise definitions for the purpose of measurement of effect.

Existing research on instructional control is limited and critically so in the design of CAVI. We are aware that learners will always differ in the degree of control they would prefer, and on how well they might be able to exercise that control if allowed directly or indirectly. We are also aware that learners always exercise some degree of control over their overt and covert learning activities during instruction regardless of treatment. Snow (1980) has suggested that, bearing the above in mind, instructional treatment variables not ostensibly concerned with learner control contrasts often have different implications for learner control of these activities. Moreover, that the question of research on learner control is too simply put if it concerns only whether or not learners are allowed to choose their own amounts, sequences, contents, or methods of instruction. The arrangement of instructional control ought to be seen in relation to a measure of prior individual dispositions (aptitude treatment interaction) than only something worthwhile could be said about learning and achievement, and instruction. There is a basic research need for a measure of differences in prior individual dispositions of learners as this is invariably a critical factor in learning achievement (Gary, 1986; Snow, 1980).

\section{References}

Fisher, M. D., \& Blackwell, L. R. (1975). The effects of student control and choice on engagement in a CAI Arithmetic task in low-income schools. Journal of Educational Psychology, 67(6), 776-783.

Gay, G. (1986). Interaction of Learner Control and prior understanding in computer-assisted video instruction. Journal of Educational Psychology, 78(3), 225-227.

Goetzfried, L., \& Hannafin, M. J. (1985). The effect of the locus of CAI control strategies on the learning of Mathematics rules. American Educational Research Journal, 22(2), 273-278.

Hannafin, M. J. (1984). Guidelines for using locus of instructional control in the design of computer-assisted instruction. Journal of Instructional Development, 7(3), 6-9. 
Hannafin, M. J., \& Colomaio, M. E. (1988). The effects of variations in lesson control and practice on learning from interactive video. Educational Communication and Technology Journal, 35(4), 203-212.

Hannafin, M. J. \& Colomaio, M. E. (1987). The effects of locus of instructional and practice on learning from interactive video. Paper presented at the Annual Meeting of the Association of Educational Communications and Technology, Atlanta, Georgia.

Holmes, N., Robson, E. H. \& Steward, A. P. (1985). Learner control in computer-assisted learning. Journal of Computer-Assisted Learning, 1, 99107.

Judd, W. A. (1972). Learner controlled computer-assisted instruction. Paper presented at the International School on Computers in Education, Pugnochiusco, Italy. (ERIC Document Number: ED 072 635).

Laurillard, D. (1984). Interactive video and the control of learning. Educational Technology, 24(6), 7-144.

Ross, S. M. \& Rakow, E. A. (1981). Learner control versus program control as adaptive strategies for selection of instructional support on Math rules. Journal of Educational Psychology, 73(5), 745-753.

Snow, R. E. (1980). Aptitude, learner control and adaptive instruction. Educational Psychologist, 15(3), 151-158.

Tennyson, R. D., Robert, D. \& Rothen, W. (1979). Management of computer-based instruction: design of an adaptive control strategy. Journal of Computer-Based Instruction, 5(3) 63-71.

Tennyson, C. L., Tennyson, R. D. \& Wolfgang, R. (1980). Content structure and instructional control strategies as design variables in concept acquisition. Journal of Educational Psychology, 72 (4), 499-505.

Tennyson R. D. (1980). Instructional control strategies and content structure as design variables in concept acquisition using computer based instruction. Journal of Educational Psychology, 72 (4), 525-532.

Tennyson, R. D. \& Buttery, T. (1980). Advisement and management strategies as design variables in computer-assisted instruction. Educational Communication and Technology Journal, 28 (3), 169-176.

Contributor: Dr Som Naidu lecturers in Instructional Science and Technology at the University of Southern Queensland. His research interests are in the areas of instructional systems design, human performance technology, instructional technology, and open and distance learning. Dr Naidu can be contacted at: University of Southern Queensland, Distance Education Centre, Queensland, 4350, Australia. Email: naidu@usq.edu.au

Please cite as: Naidu, S. (1995). Definitions of instructional control in learning environments. Australian Journal of Educational Technology, 11(1), 1219. http: / / www.ascilite.org.au/ajet/ajet11 / naidu.html 